KREATIF

Jurnal Ilmiah

Prodi Manajemen Universitas Pamulang
ISSN: 2339-0689 (Print), ISSN 2406-8616 (Online)

Volume 7, No 1 Juni 2019, (Halaman 55-65)

Tersedia online di http://openjournal.unpam.ac.id/index.php/kreatif

\title{
PENGARUH PEMBERIAN KOMPENSASI DAN KOMITMEN ORGANISASIONAL TERHADAP TURNOVER INTENTION PADA KARYAWAN DIVISI KEPERAWATAN EKA HOSPITAL BSD
}

\author{
Dodi Prasada \\ Program Studi Manajemen \\ Universitas Pamulang \\ dosen02454@unpam.ac.id
}

\begin{abstract}
ABSTRAK
Tujuan dari dilakukannya penelitian ini adalah untuk mengetahui seberapa besar pengaruh pada pemberian kompensasi dan komitmen organisasi terhadap turnover intention karyawan divisi keperawatan Eka Hospital BSD.

Penelitian ini memakai metode pendekatan deskriftif dan kuantitatif,dengan menggunakan analisis data pengujian validitas dan reliabilitas, pengujian normalitas dengan uji kolmogorov smirnov, analisis regresi, pengujian parsial, pengujian simultan dan koefisien determinasi. Jumlah sampel yang dipakai adalah 68 orang dari jumlah keseluruhan populasi yaitu 271 orang pada karyawan divisi keperawatan Eka Hospital BSD. Dalam pengumpulan data peneliti menggunakan sampel random sampling dengan teknik wawancara, diskusi dan penyebaran angket kuesioner.

Hasil dari penelitian, pada hipotesis pertama : adanya pengaruh dan signifikan pada pemberian kompensasi terhadap turnover intention ditandai dengan hasil uji regresi diperoleh persamaan $\mathrm{Y}=24,042-0257 \mathrm{X} 1$ dan pada nilai koefisien determinasi $\mathrm{R}$ squere sebesar 0,066. Pada hipotesis kedua : adanya pengaruh dan signifikan pada komitmen organisasi terhadap turnover intention ditandai dengan hasil pengujian analisis persamaan regresinya $Y=31,185-0,342 X 2$ dan pada nilai koefisien determinasi $\mathrm{R}$ squere sebesar 0,117. Dan pada hipotesis ketiga : Pada analisis regresinya didapati persamaan $\mathrm{Y}=32,467-0,116 \mathrm{X} 1-0,291 \mathrm{X} 2$, konstanta sebesar 32,467 , pada pengujian sumultan uji $\mathrm{F}$ diperoleh hasil $\mathrm{F}$ hitung 5,391 $\geq \mathrm{F}$ tabel 3,13 pada taraf signifikan sebesar $0,007 \leq 0,05$. Berdasarkan hasil tersebut berarti pada pemberian kompensasi serta komitmen organisasional yang dilakukan secara bersamaan akan berpengaruh dan signifikan terhadap turnover intention.
\end{abstract}

Kata kunci : Kompensasi, komitmen organisasional, Turnover Intention

\section{ABSTRACT}

The purpose of this research is to find out how much influence on the provision of compensation and organizational commitment to the employee turnover intention of the Eka Hospital BSD nursing division.

This research uses descriptive and quantitative approaches, using validity and reliability testing data analysis, normality testing with Kolmogorov Smirnov test, regression analysis, partial testing, simultaneous testing and coefficient of determination. The number of samples used was 68 people from the total population of 271 people in the Eka Hospital BSD nursing division employees. In collecting data researchers used random sampling with interview, discussion and questionnaire questionnaires.

The results of the study, in the first hypothesis: the influence and significance of compensation for turnover intention is indicated by the results of the regression test 
obtained by the equation $Y=24.042-0257 X 1$ and the coefficient of determination $R$ squere of 0.066. In the second hypothesis: the influence and significant on organizational commitment to turnover intention is indicated by the results of the analysis of the regression equation $Y=31.185-0.334 X 2$ and the value of the coefficient of determination $R$ squere of 0.117. And in the third hypothesis: In the regression analysis found the equation $Y=32,467-0,116 X 1-0,291 X 2$, a constant of 32,467, in the $F$ test the simultaneous test obtained $F$ count results of $5.391 \geq F$ table 3.13 at a significant level of $0.007 \leq 0.05$. Based on these results it means that the provision of compensation and organizational commitment that is carried out simultaneously will have a significant and significant effect on turnover intention.

Keywords: Compensation, organizational commitment, Turnover Intention

\section{PENDAHULUAN}

\section{A. Latar Belakang}

Sumber daya manusia merupakan modal terpenting dalam sebuah perusahaan, hal ini disebabkan karena manusia merupakan sumber daya yang penuh semangat dan selalu dibutuhkan dalam proses produksi bail barang maupun jasa. Saat ini perkembangan manajemen dalam perusahaan khususnya dalam manajemen sumber daya manusia dituntut agar lebih memperhatikan kebijakan yang ada dalam perusahaan dalam pekerjaan. Dalam menjalankan kebijakan yang tidak sesuai dengan yang diterapkan akan membawa dampak buruk kepada sikap pekerja. Oleh karena itu dalam menjalankan efesiensi dan efektifitas dalam sumber daya manusia perlu adanya kesadaran sehingga dapat bersaing dan memiliki keunggulan yang komfetitif.

Perkembangansumberdaya manusia didalam lingkungan perusahaan semakin pesat berkembang saat ini, seiring dengan semakin besarnya persaingan dalam dunia industri dan organisasi. Salah satu aspek penting perusahaan menyiapkan sumber daya manusia yang unggul.

Rumah sakit adalah salah satu bentuk pelayanan kesehatan yang membutuhkan sumber daya manusia yang dapat bekerja secara professional. Dalam mencegah permasalahan yang terjadi dalam lingkungan rumah sakit yaitu dengan menjaga nilai pelayanan terhadap masyarakat.

Turnover dapat diartikan yaitu adanya keinginan dari seorang karyawan untuk keluar atau berhenti bekerja. Turnoverpun dapat dilihat dalam bentuk adanya perpindahan, pengunduran diri, pemecatan ataupun adanya kematian seorang karyawan.

Dalam memprediksi tingginya tingkat turnover karyawan dalam perusahaan yaitu dengan seberapa besar keinginan pindah dari seorang karyawan dalam perusahaan. Sebuah penelitian menunjukan salah satu penyebab adanya keinginan karyawan untuk keluar adalah berkaitan erat dengan kepuasan dalam penerimaan kompensasi dan juga adanya komitmen organisasi.

Pemberian kompensasi dapat juga dihubungkan dengan keinginan keluar karyawan (turnover intention) akan tetapi dari factor lainpun ikut adil dalam hal ini, seperti kondisi pasar kerja, kesempatan kerja dan lamanya masa kerja merupakan hal yang dapat seorang karyawan meninggalkan pekerjaanya. Akan tetapi bila bila seorang karyawan merasa terpuaskan dengan pekerjaannya maka karyawan tersebut cenderung untuk tetap bertahan dalam perusahaan.

Bedahalnya ketika seorang karyawan merasa kurang terpuaskan maka karyawan tersebut akan memili8h keluar dari perusahaan. 
Komitmen organisasional dapat berkontribusi penting dalam memprediksi variabel-variabel dalam perusahaan yang terhubung dengan intense keluar. Komitmen organisasional juga merupakan hal yang kuat bagi karyawan untuk melakukan pindah kerja.

Tabel 1.1

Data Turnover Karyawan Divisi Keperawatan Eka Hospital BSD

\begin{tabular}{|c|c|c|c|c|c|c|c|c|c|c|c|c|c|}
\hline Bulan & $\operatorname{Jan}$ & $\mathrm{Feb}$ & Mar & Apr & Mei & Jun & Jul & Ags & Sep & Okt & Nov & Des & $\mathrm{Jml}$ \\
\hline \multicolumn{14}{|c|}{ Tahun 2012} \\
\hline Masuk & 5 & 10 & 2 & 6 & 0 & 1 & 1 & 0 & 5 & 7 & 8 & 28 & 73 \\
\hline$\%$ & 1,38 & 2,77 & 0,55 & 1,66 & 0 & 0,27 & 0,27 & 0 & 1,38 & 1,94 & 2,22 & 7,77 & 20,27 \\
\hline$\overline{\text { Keluar }}$ & 5 & 1 & 6 & 4 & 3 & 4 & 1 & 7 & 3 & 4 & 3 & 8 & 49 \\
\hline$\%$ & 1,38 & 0,27 & 1,66 & 1,11 & 0,83 & 1,11 & 0,27 & 1,94 & 0,83 & 1,11 & 0,83 & 2,22 & 13,61 \\
\hline \multicolumn{13}{|c|}{ Jml Tenaga } & 360 \\
\hline \multicolumn{14}{|c|}{ Tahun 2013} \\
\hline$\overline{\text { Masuk }}$ & 6 & 1 & 1 & 3 & 3 & 9 & 1 & 2 & 10 & 15 & 0 & 0 & 51 \\
\hline$\%$ & 1,64 & 0,27 & 0,27 & 0,82 & 0,82 & 2,47 & 0,27 & 0,54 & 2,74 & 4,12 & 0 & 0 & 14,01 \\
\hline Keluar & 1 & 5 & 9 & 4 & 4 & 2 & 6 & 5 & 3 & 3 & 1 & 4 & 47 \\
\hline$\%$ & 0,27 & 1,37 & 2,47 & 1,09 & 1,09 & 0,54 & 1,64 & 1,37 & 0,82 & 0,82 & 0,27 & 1,09 & 12,91 \\
\hline \multicolumn{13}{|c|}{ Jml Tenaga } & 364 \\
\hline \multicolumn{14}{|c|}{ Tahun 2014} \\
\hline Masuk & 0 & 1 & 8 & 0 & 0 & 0 & 0 & 1 & 5 & 7 & 7 & 0 & 29 \\
\hline$\%$ & 0 & 0,3 & 2,43 & 0 & 0 & 0 & 0 & 0,3 & 1,52 & 2,13 & 2,13 & 0 & 8,84 \\
\hline Keluar & 2 & 4 & 11 & 4 & 6 & 5 & 7 & 1 & 6 & 6 & 3 & 10 & 65 \\
\hline$\%$ & 0,6 & 1,21 & 3,35 & 1,21 & 1,82 & 1,52 & 2,13 & 0,3 & 1,82 & 1,82 & 0,91 & 3,04 & 19,81 \\
\hline
\end{tabular}

Jadi dapat dilihat hasil presentase dari jumlah karyawan divisi keperawatan Eka Hospital BSD yang keluar dari tahun 2012, 2013 dan 2014, memiliki tingkat turnover sebesar $13,61 \%=49$ orang, $12,91 \%=47$ orang dan $19,81 \%=65$ orang. Disetiap ketentuan atau peraturan perusahaan tidaklah sama, maka dari itu tidaklah ada patokan dalam menilai mengenai angka turnover yang pasti.

Akan tetapi berdasarkan struktur karyawan yang ada di divisi keperawatan Eka Hospital BSD, maka penilaian tingkat rata-rata turnover ini bisa menjadikan masalah besar bagi perusahaan.

Terlihat pula masih adanya turnover karyawan divisi keperawatan Eka Hospital BSD selama tiga tahun. Hal ini memberi tanda adanya penyebab pencetus mengapa karyawan pada divisi keperawatan ini memilih keluar. Dari beberapa penyebab diduga adanya pengaruh pemberian kompensasi dan komitmen organisasi sebagai peran penting yang signifikan. Dengan alasan tersebut maka penelitian ini dilakukan dan judul yang diambil dalam penelitian

ini adalah: "Pengaruh Pemberian Kompensasi Dan Komitmen

Organisasional Terhadap Turnover Intention Pada Karyawan Divisi Keperawatan Eka Hospital BSD".

\section{B. Perumusan Masalah}

Berdasarkan latar belakang masalah diatas maka penelitian ini dilakukan untuk menguji pengaruh pemberian kompensasi dan komitmen organisasional terhadap turnover intention (niat ingin berhenti kerja) sehingga masalah yang diteliti dalam penelitian ini dapat dirumuskan sebagai berikut : 
1. Apakah pemberian kompensasiberpengaruh positif dan signifikan terhadap turnover intention pada karyawan divisi keperawatan Eka Hospital BSD?

2. Apakah komitmen organisasional berpengaruh positif dan signifikan terhadap

turnover intention pada karyawan divisi keperawatan Eka Hospital BSD ?

3. Apakah pemberian kompensasi dan komitmen organisasional berpengaruh positif dan signifikan secara bersama-sama terhadap turnover intention pada karyawan divisi keperawatan Eka Hospital BSD ?

\section{TINJAUAN PUSTAKA}

\section{A. Pengertian Turnover Intention}

Pada dasarnya turnover intention adalah adanya niat atau keinginan berpindahnya seorang karyawan dari satu tempat kerja ke tempat kerja lain. Dalam hal ini seorang karyawan itu belum sampai pada tahap melakukan perpindahan ke tempat kerja yang baru.

Menurut pendapat Handoko (2000:322) menyatakan "Turnover intention merupakan tantangan yang khusus bagi pertumbuhan sumber daya manusia, karena kejadian-kejadian tersebut tidak dapat diprediksi, kegiatan-kegiatan pengembangan harus dipersiapkan setiap saat pengganti karyawan yang keluar". Dan menurut Gillis dalam Bambang Aryanto (2011:6) berpendapat bahwa "Keluarnya petugas perawat dari rumah sakit dikatakan normal berkisar diantara 5 - $10 \%$ per tahunnya dan dikatakan tinggi apabila tingkat turnovernya lebih dari $10 \% "$

Menurut Simamora dalam Rita Andini (2006:11) "Dalam mengukur tingkat turnover pada perusahaan dapat menggunakan rumus", sebagai berikut:

Tingkat Turnover $=$ Jumlah karyawan keluar dalam 1 periode $:$ Jumlah total karyawan dalam 1 periode X $100 \%$

Rata-rata karyawan dalam 1 periode $=$ Jumlah karyawan awal periode + Jumlah karyawan akhir periode : Jumlah keseluruhan karyawan dalam periode

\section{Dimensi Turnover Intention}

Widodo (2014:41) mengemukakan ada tiga dimensi yang dapat digunakan untuk membangun niat ingin keluar (turnover intention), yaitu :

a. Pikiran untuk keluar, keinginan keluar ini biasanya terjadi ketika adanya permasalah dalam bekerja seperti adanya permasalahan dengan seorang atasan, adanya hubungan yang sudah tidak harmonis dengan rekan kerja. Sehingga menimbulkan ketidak betahan dalam bekerja dan terpikirkan untuk pindah tempat kerja.

b. Adanya keinginan mendapatkan pekerjaan lain, biasanya terjadi karena ada beberapa factor yang menjadi alasan seperti meningkatnya kebutuhan hidup, sedangkan gaji yang diperoleh saat ini tidak ada peningkatan dan dapat pula alasan bahwa karyawan merasa bosan dengan pekerjaan yang dilakukan saat ini, beban kerja yang terasa berat yang dirasakan karyawan sehingga karyawan memutuskan untuk mencari pekerjaan yang lebih baik.

c. Adanya keinginan untuk meninggalkan perusahaan dalam beberapa bulan kedepan. Sikap seorang karyawan yang suka pindah-pindah pekerjaan biasanya dilator belakangi oleh karekter perilaku karyawan itu sendiri, seperti merasa tidak betah kerja atau hanya ingin mendapatkan pengalaman saja. 


\section{B. Pengertian Pemberian Kompensasi}

Malayu Hasibuan (2003:118) menyatakan "Pemberian Kompensasi adalah semua pendapatan yang berbetuk uang, barang langsung maupun tidak langsung yang diterima oleh karyawan sebagai bentuk imbalan jasa dari perusahaan".

Menurut pendapat Lum et.al dalam Agung Wahyu (2012:5) berpendapat bahwa "Seorang karyawan akan merasa terpuaskan dengan gajinya ketika gajih yang mereka peroleh sudah sesuai dengan apa yang mereka harapkan". Dalam beberapa penelitian mengemukakan bahwa aspek kepuasan dalam pemberian kompensasi berhubungan dengan adanya keinginan seseorang karyawan untuk meninggalkan perusahaannya.

Mangkunegara (2013:83) mendefinisikan "Pemberian kompensasi merupakan satu hal yang dapat dipertimbangkan sebanding". Bentuk-bentuk dalam pemberian upah dan gaji digunakan untuk mengatur antara majikan dengan karyawannya.

\section{Dimensi Pemberian Kompensasi}

Menurut Heneman dan Schwab dalam Rita Andini (2006:15) menyatakan bahwa " pemberian kompensasi merupakan gambaran yang multidimensi yang terdri dari empat subdimensi : (1) tingkat gaji dapat dilihat dari berapa besarnya kompensasi yang diterima oleh seorang karyawan, (2) struktur gaji dilihat dari adanya perubahan kenaikan dalam penerimaan kompensasi seorang karyawan dalam mengemban jabatan disebuah unit kerjanya (3) peningkatan gaji: dilihat dari kenaikan kompensasi yang diterima secara langsung oleh karyawan, dan tunjangan: dilihat dari segi penerimaan kompensasi secara tidak langsung oleh seorang karyawan.

\section{Pengertian Komitmen Organisasional}

Menurut pendapat dari Mowdey dalam Agung Wahyu (2012:5) mengemukakan "Sebuah komintmen dalam organisasi adalah :

1. adanya kepercayaan yang besar terhadap organisasi, nilai dan tujuan sebuah organisasi,

2. adanya keinginan dan niat yang kuat dalam mempertahanka keanggotaanya organisasi,

3. adanya niat yang besar dalam memberikan yang terbaik untuk perusahaan".

Rita Andini (2006:56) menyatakan bahwa "Seorang karyawan yang berkomitmen tinggi dapat memberikan kontribusi yang tinggi dan akan merasa senang dalam membangun perkembangan perusahaan secara bersama-sama".

Bagi seorang karyawan yang loyal serta setia kepada

perusahaannya dan mampu memberikan komitmen yang tinggi terhadap perusahaan maka akan membuat sebuah perusahaan menjadi kuat dan sukses secara bersama-sama dan menjadikan karyawan itu merasa puas. Sedangkan seorang yang merasa tidak terpuaskan dalam lingkungan kerjanya maka dia akan menarik diri dari perusahaannya.

Dengan demikian dalam melakukan usaha pencapaian tujuan perusahaan yang diinginkan maka diperlukan adanya rasa komitmen karyawan yang kuat dan komitmen perusahaan dalam mempertahankan karyawannya.

\section{Dimensi Komitmen Organisasional}

Dari berbagai bentuk cara berkomitmen, baik yang dijalankan oleh karyawannya ataupun dari perusahaanya, Allen dan Mayer dalam Nora Sri (2013:35) menyebutkan adanya tiga dimensi yang bisa membangun rasa komitmen antar karyawannya. 
(1) Komitmen efektif, yaitu adanya hubungan dengan rasa emosiaonal dan keterlibatan, adanya rasa peduli dan siap berkorban dari setiap karyawannya yang tercipta atas keinginannya sendiri.

(2) Komitmenyang berkesinambungan, yaitu adanya rasa setia dari individu karyawannya sehingga memutuskan akan tetap berada dalam perusahaan karena mengganggap dengan bekerja maka dapat memenuhi segala kebutuhannya.

(3) Komitmen normative, yaitu adanya rasa yakin dari seorang karyawan terhadap perusahaannya sehingga dirinya memiliki kewajiban untuk loyal kepada perusahaannya tersebut.

\section{METODOLOGI PENELITIAN}

\section{A. Ruang Lingkup Penelitian}

Ruang lingkup dalam penelitian ini adalah pengaruh pemberian kompensasi dan komitmen organisasional terhadap turnover intention pada karyawan divisi keperawatan Eka Hospital BSD dan yang menjadi objek pada penilitian adalah seluruh karyawan pada divisi keperawatan Eka Hospital BSD yang beralamat di CBD Lot IX, BSD City, Serpong - Tangerang Selatan, proses penelitian ini dilakukan selama enam bulan yaitu dimulai dari bulan april 2015 sampai September 2015.

\section{B. Metode Penentuan Sempel}

Menurut Sugiyono (2011:81) menyatakan "Sebuah sempel dapat diartikan sebagai suatu bagian yang di ambil dari populasi". Jadi dapat diperjelas bahwa sempel adalah bagian dari populasi yang memiliki cirri-ciri atau keadaan tertentu yang akan diteliti. Dalam penelitian ini jumlah dari keseluruhan populasi diambil dari karyawan divisi keperawatan yang jumlah seluruhnya adalah 271 orang.

Menurut pendapat dari Arikunto (2010:174) mengatakan "Sampel adalah sebagian atau wakil dari populasi yang diteliti". Rumus yang dipakai dalam pengambilan sampel ini adalah :

$\mathrm{n}=25 \% \mathrm{XN}$

Keterangan $: \mathrm{n}=$ jumlah sampel dan $\mathrm{N}=$ jumlah populasi

(Arikunto (2006:185))

Maka dalam penelitian ini, jumlah sampelnya yaitu :

$\mathrm{n}=25 \%$ X $271=67,75$

Jadi jumlah sampel adalah 68 orang responden.

\section{Metode Pengumpulan Data}

Dalam penelitian ini menggunakan metode pengumpulan data yaitu dengan menggunakan metode observasi, wawancara dan teknik kuesioner.

\section{Metode Analisis Data}

Metode analisis data yang digunakan dalam penelitian ini adalah uji validitas, uji reliabilitas, koefisien determinasi dan uji hipotesis.

\section{HASIL PENELITIAN DAN PEMBAHASAN}

\section{A. Sejarah Singkat Eka Hospital BSD}

Berikan pelayanan kesehatan yang berkualitas dengan staf yang berdedikasi tinggi dan professional serta didukung dengan teknologi terkini dan standar fasilitas kesehatan yang baik. Mulai beroperasi pada 20 Agustus 2008, Eka Hospital BSD yang berlokasi dikawasan bisnis CBD Lot IX, BSD city - Tangerang Selatan, dengan jumlah 40 ruangan klinik rawat jalan dan lebih dari 180 tempat tidur pada ruang rawat inap. 
Saat ini Eka Hospital BSD Merupakan rumah sakit rujukan untuk pusat layanan saraf, jantung dan pembuluh darah, ibu dan anak, layanan bedah akses minimal, unit gawat darurat 24 jam, serta medical check up.

B. Visi dan Misi Eka Hospital BSD

Visi : "Menjadi jaringan penyedia layanan kesehatan terdepan di Asia Pasific"

Misi : (1) Mengutamakan keselamatan dan kenyamanan pasien, (2) Menerapkan standar layanan medis yang terbaik, (3) Menyediakan layanan kesehatan terpadu, (4) Melayani dengan tulus dan sepenuh hati, (5) Aktif mempromosikan hidup sehat.

C. Analisis Pemberian Kompensasi Pada Divisi Keperawatan Eka Hospital BSD.

Berdasarkan hasil data kuesioner pada penilitian ini dapat dilihat bahwa dari seluruh responden yang berjumlah 68 orang, dan data kesioner 13 butir pernyataan yang berhubungan langsung dengan indikator pemberian kompensasi terlihat responden menjawab dengan presentase tertinggi adalah "Tidak Setuju" (TS) sebesar 36\% dan terendah menjawab "Sangat Setuju”(SS) sebesar 2\%.

D. Analisis Komitmen Organisasional Pada Divisi Keperawatan Eka

\section{Hospital BSD}

Berdasarkan hasil data kuesioner pada penilitian ini dapat dilihat bahwa dari seluruh responden yang berjumlah 68 orang, dan data kesioner 15 butir pernyataan yang berhubungan langsung dengan indikator komitmen organisasional terlihat responden menjawab dengan presentase tertinggi adalah "Setuju"

sebesar52\% dan terendah menjawab "Tidak Setuju"(TS) sebesar 1\%.

\section{E. Analisis Turnover Intention Pada Divisi Keperawatan Eka Hospital BSD}

Berdasarkan hasil data kuesioner pada penilitian ini dapat dilihat bahwa dari seluruh responden yang berjumlah 68 orang, dan data kesioner 7 butir pernyataan yang berhubungan langsung dengan indikator turnover intention terlihat responden menjawab dengan presentase tertinggi adalah "Tidak Setuju" (TS) sebesar 30\% dan terendah menjawab "Sangat Tidak Setuju"(STS) sebesar 6\%.

\section{F. Pengujian Instrumen}

\section{Uji Validitas}

Kuesioner dalam penelitian ini terbagi dalam tiga factor utama, yaitu pemberian kompensasi (X1) dengan 13 butir pernyataan, komitmen organisasional (X2) dengan 15 butir pernyataan dan turnover intention (Y) dengan 7 butir pernyataan. Jadi jumlah keseluruhan pernyataan dalam kuesioner penelitian ini adalah sebanyak 35 butir pernyataan. Jumlah responden (sampel) pada uji validitas ini adalah 68 orang responden.

Dalam lampiran tabel Sugiyono (2010:333) untuk mengetahui nilai r tabel product moment kuesioner pada tingkat kemaknaan 5\% dengan jumlah sampel 68 orang, maka didapati angka $r$ tabelnya yaitu 0,239. Masing-masing pernyataan bila dibandingkan dengan nilai $r$ hasil dengan ketentuan $r$ hasil $>r$ tabel maka pernyataan tersebut dinyatakan valid.

Dan dapat disimpulkan dari uji validitas dalam penelitian ini dari 35 butir pernyataan terdapat 3 butir pernyataan yang dinyatakan tidak valis, dikarenakan nilai corrected item $<0,239$, sedangkan yang dinyatakan valid nilai corrected item $>0,239$. Langkah selanjutnya peneliti melakukan analisis ulang dengan membuang butir-butir pernyataan yang dianggap tidak valid. Dan butir pernyataan yang dipakai berjumlah 32 butir pernyataan dan selanjutnya itemitem tersebut dapat dipakai dalam pengujian regresi. 


\section{Uji Reliabilitas}

Dalam penelitian ini untuk melakukan uji reliabilitas dipakai metode alpha cronbach, dengan ketetapan yang digunakan dalam menentukan uji reliabilita adalah dengan membandingan dari nilai $r$ hitung diwakili dengan alpha dengan $\mathrm{r}$ tabel pada taraf kepercayaan $95 \%$ atau tingkat signifikan $5 \%$.

Menurut Arikunto (2010:205) menyatakan "Bahwa suatu instrument cukup dapat dipercaya untuk digunakan sebagai alat pengumpulan data". Tingkat reliabilitas dengan alpha cronbach diukur berdasarkan skala alpha $0-1$.

Hasil uji reliabilitas pada penelitian ini dapat disimpulkan bahwa pada variabel kompensasi (X1) nilai cronbach alpha 0,910, pada variabel komitmen organisasional (X2) nilai cronbach alpha 0,879 dan pada variabel turnover intention (Y) didapat nilai cronbach alpha 0,850 . Sehingga berdasarkan tabel $\mathrm{r}$ alpha cronbach yang didapat pada penilitian ini didapatkan hasil sangat reliable dan layak untuk disebarkan pada responden.

\section{Uji Normalitas Data}

Uji ini dilakukan untuk mendeteksi apakah residual berdistribusi normal atau tidak. Dalam penelitian ini uji normalitas menggunakan uji kolmogorov smirnov yaitu dengan cara membandingkan distribusi data dengan distribusi normal baku. Dimana jika nilai signifikan dibawah 0,05 berarti terdapat perbedaan yang signifikan dan dinyatakan data tidak normal, sedangkan jika nilai signifikan diatas 0,05 maka tidak terjadi perbedaan yang signifikan dan dinyatakan data normal.

Dari hasil penelitian ini dapat disimpulkan dan diperoleh nilai signifikan dari variabel kompensasi (X1) sebesar 0,629 dan pada variabel komitmen sebesar 0,106 dimana nilai signifikan dari masing-masing variabel lebih besar dari 0,05, sehingga dapat diartikan bahwa distribusi data dikatakan normal.

\section{Uji Hipotesis Penelitian Uji Parsial (Uji t)}

Sebagai pembanding dalam melihat pengaruh signifikan, maka dipakai criteria taraf signifikan sebesar 5\% $(0,05)$ dengan membandingkan nilai t hitung dengan nkriteria sebagai berikut :

1) Jika hasilnya yang didapat positif

t hitung $>\mathrm{t}$ tabel berarti Ho ditolak dan Ha diterima

t hitung $<\mathrm{t}$ tabel berarti Ho diterima dan Ha ditolak

2) Jika hasilnya yang didapat negative

thitung $(-)<$ t tabel (-) berarti Ho ditolak dan Ha diterima

t hitung (-) > t tabel (-) berarti Ho diterima dan Ha ditolak

Dalam penentuan t tabel dapat menggunakan cara membandingkan

jumlah sampel dengan taraf signifikan. Rumus yang dipakai yaitu :

t tabel $=($ tingkat kepercayaan dibagi 2 ; jumlah responden dikurangi jumlah variabel bebas dikurangi 1), maka jika di tulis dalam rumus pada penelitian ini didapati hasil :

$\mathrm{t}$ tabel $=(0,05 / 2 ; 68-2-1)$

$\mathrm{t}$ tabel $=(0,025 ; 65)$

Lalu bila dilihat dalam distribusi nilai $\mathrm{t}$ tabel, $\mathrm{df}=65$ pada kolom 0,025 , maka didapati nilai t tabel sebesar 1,998 atau $(-1,998)$.

\section{Pengaruh Kompensasi Terhadap Turnover Intention}

Berdasarkan hasil output data dapat diperoleh sebagai berikut : Nilai koefisien determinasi $\mathrm{R}$ squere sebesar 0,066, artinya hasil data mengindikasikan bahwa kompensasi terhadap turnover intention memberikan 
nilai kontribusi sebesar 6,6\% dan sisanya sebesar $93,4 \%$ didapat dari variabel lain diluar penelitian ini.

Model regresi yang didapat dalam penelitian ini adalah $\mathrm{Y}=24,042-0,257 \mathrm{X} 1$, artinya :

1) Konstanta sebesar 24,042 menggambarkan bahwa tanpa kompensasi, turnover intention tetap terbentuk sebesar 24,042.

2) Variabel kompensasi berpengaruh negative terhadap turnover intention dengan nilai koefisien sebesar -0,257, tanda negative pada nilai koefisien melambangkan hubungan yang berlawanan antar kompensasi dan turnover intention. Artinya apabila kompensasi semakin meningkat, maka turnover intention karyawan akan mengalami penurunan sebesar - 0,257.

3) Nilai t hitung lebih kecil dari t tabel yaitu sebesar $-2.156<-1,998$ dan taraf signifikasi t lebih kecil 0,035 <0,05, maka Ho ditolak dan Ha diterima.

4) Hasil ini menunjukan bahwa terdapat pengaruh negative dan signifikan pemeberian kompensasi terhadap turnover intention.

\section{Pengaruh Komitmen Organisasional Terhadap Turnover Intention}

Berdasarkan output data dapat diperoleh hasil sebagai berikut : Nilai koefisien determinasi $\mathrm{R}$ squere sebesar 0,117, artinya hasil data mengindikasikan bahwa komitmen organisasional terhadap turnover intention memberikan nilai kontribusi sebesar $11,7 \%$ dan sisanya sebesar $88,3 \%$ didapat dari variabel lain diluar penelitian ini.

Model regresi yang didapat dalam penelitian ini adalah $Y=31,185-0,342 X 2$, artinya :

1) Konstanta sebesar 31,185 menggambarkan bahwa tanpa komitmen organisasional, turnover intention tetap terbentuk sebesar 31,185.

2) Variabel komitmen organisasional berpengaruh negative terhadap turnover intention dengan nilai koefisien sebesar -0,342, tanda negative pada nilai koefisien melambangkan hubungan yang berlawanan antar komitmen organisasional dan turnover intention. Artinya apabila komitmen organisasional semakin meningkat, maka turnover intention karyawan akan mengalami penurunan sebesar 0,342 .

3) Nilai t hitung lebih kecil dari t tabel yaitu sebesar $-2.960<-1,998$ dan taraf signifikasi t lebih kecil 0,035 < 0,05, maka Ho ditolak dan $\mathrm{Ha}$ diterima. Hasil ini menunjukan bahwa terdapat pengaruh negative dan signifikan komitmen organisasional terhadap turnover intention.

\section{Uji Simultan (Uji F)}

Dalam menguji pengaruh pemberian kompensasi dan komitmen organisasional secara bersama-sama terhadap turnover intention, dapat dilakukan uji statistik F (uji simultan). Sebagai pembanding dalam melihat pengaruh signifikan, maka dapat digunakan criteria taraf signifikan sebesar 5\% $(0,05)$ dengan cara membandingkan $F$ hitung dengan $F$ tabel, dan dapat dijelaskan sebagai berikut :

1) Jika $F$ hitung $<F$ tabel maka Ho diterima dan Ha ditolak

2) Jika $F$ hitung $>F$ tabel maka Ho ditolak dan Ha diterima 
Adapun kketentuan $\mathrm{F}$ tabel diperoleh dengan cara membandingkan jumlah variabel independen dengan taraf signifikan (2 variabel : 0,05), maka didapati nilai $F$ tabel sebesar 3,13.

Berdasarkan hasil output diperoleh data sebagai berikut : Model regresi yang didapat dalam penelitian ini adalah $\mathrm{Y}=32,467-0,166 \mathrm{X} 1-0,291 \mathrm{X} 2$.

1) Konstanta sebesar 32,467 menggambarkan bahwa tanpa kompensasi dan komitmen organisasional, turnover intention tetap terbentuk sebesar $32,467$.

2) Pemberian kompensasi berpengaruh negatif terhadap turnover intention dengan nilai koefisien $-0,166$. Tanda negatif menggambarkan hubungan yang berlawanan antara pemberian kompensasi dan turnover intention. Artinya bila pemberian kompensasi semakin besar, dengan asumsi komitmen organisasional tetap, maka turnover intention karyawan dapat mengalami penurunan sebesar -0,166.

3) Komitmen organisasional berpengaruh negatif terhadap turnover intention dengan besaran nilai koefisiennya -0,291. Tanda negatif menggambarkan hubungan yang berlawanan antara komitmen organisasional dan turnover intention. Dapat diartikan apabila komitmen organisasional semakin besar, dengan asumsi pemberian kompensasi tetap, maka turnover intention karyawan dapat mengalami penurunan sebesar $-0,291$.

4) Nilai koefisien determinasi $\mathrm{R}$ squere 0,142 , dapat diartikan bahwa data tersebut menggambarkan pemberian kompensasi dan komitmen organisasional secara bersama-sama mempunyai nilai kontribusi sebesar $14,2 \%$ terhadap turnover intention dan selebihnya sebesar 85,8 dipengaruhi oleh variabel lain diluar penelitian ini.

5) Didapati data nilai $F$ hitung lebih besar dari $F$ tabel, yaitu 5,391 > 3,13 dengan taraf siginikan $\mathrm{F}$ sebesar $0,007<0,05$, maka dapat dijelaskan $\mathrm{H} 3$ diterima dan Ho ditolak. Hasil ini memberikan arti bahwa pemberian kompensasi dan komitmen organisasional secara bersama-sama berpengaruh positif dan signifikan terhadap turnover intention.

\section{KESIMPULAN}

Penelitian ini dilakukan pada karyawan divisi keperawatan Eka Hospital BSD dengan menganalisa pengaruh pemberian kompensasi dan komitmen organisasional terhadap turnover intention. Berdasarkan hasil penelitian dan analisa, maka dapat diambil kesimpulan sebagai berikut :

1. Pertama, Pemberian kompensasi terbukti berpengaruh dan signifikan terhadap turnover intention pada karyawan divisi keperawatan Eka Hospital BSD. Hal ini juga menandakan masih adanya karyawan yang belum merasa terpuaskan pada pemberian kompensasi yang diterimanya dan ini dapat berakibatkan adanya keinginan karyawan untuk melakukan turnover.

2. Kemudian, komitmen organisasional terbukti berpengaruh dan sigifikan terhadap turnover intention pada karyawan divisi keperawatan Eka Hospital BSD. Hal ini menunjukkan bahwa semakin tingginya komitmen organisasional akan berpengaruh terhadap penurunan angka turnover, begitu pula sebaliknya jika komitmen organisasional semakin rendah maka akan berdampak negatif bagi perusahaan sehingga akan semakin tinggi tingkat turnover intention.

3. Dan yang terakhir, pemberian kompensasi dan komitmen organisasional secara bersama-sama berpengaruh dan signifikan terhadap turnover intention pada 
karyawan divisi keperawatan Eka Hospital BSD. Hal ini menunjukan bahwa bila rendahnya pemberian kompensasi dan tidak adanya komitmen dalam perusahaan secara bersamaan, maka akan mempengaruhi tingginya angka turnover intention. Begitupun sebaliknya bila pemberian kompensasi dan komitmen ornasisasi meningkat maka akan menurunkan angka turnover intention karyawan.

\section{SARAN}

Berdasarkan hasil penelitian maka saran nya ialah:

1. Pertama, dari hasil data analisis pada pemberian kompensasi, diharapkan pada pihak manajemen untuk adanya perubahandantetap meningkatkan serta mempertahankan yang telah berjalan dengan baik, yaitu tetapadanyapemberian tunjangan-tunjanganyang sesuai dengan melihat kontribusi yang diberikan karyawan kepada perusahaan. Mungkin dirasa perlu adanya pemberian penghargaan berupa insentif yang diberikan secara adil dan merata, sehingga karyawan tidak akan berfikir untuk meninggalkan perusahaan.

2. Kemudian, berdasarkan hasil perhitungan koesioner untuk variabel komitmen organisasional masih terlihat lemah dibandingkan pada variabel lainnya, artinya perlu bagi pihak manajemen untuk terus mengupayakan dan meningkatkanfactorfaktor yang dapat membangun komitmen dalam organisasi, misalnya dengan meningkatkan loyalitas karyawan terhadap prusahaan, meningkatkan kesadaran kepada karyawan bahwa karyawan memiliki peran penting dalam memajukan perusahaan. Dengan hal ini diharapkan akan meningkatkan komitmen karyawan dan organisasi.

3. Point terakhir, berdasarkan hasil analisis regresi berganda bahwa pemberian kompensasi dan komitmen organisasional bila secara bersamaan maka akan mempengaruhi signifikannya pada tingginya angka turnover intention. Oleh karena itu perlu bagi manajemen untuk tetap menselaraskan dan tetap meningkatkan factor-faktor yang dapat memberikan kompensasi yang baik, adanya peningkatan rasa komitmen antara karyawan dan perusahaan sehingga keinginan karyawan untuk berhenti dapat dihindari.

\section{DAFTAR PUSTAKA}

Andini, Rita. (2006). Pengaruh Kepuasan Gaji, Kepuasan Kerja dan Komitmen Organisasional Terhadap Turnover Intention”. Semarang: Tesis, Pasca Sarjana Magister Manajemen, Univ. Diponegoro.

Arikunto, Suharsimi. (2010). Prosedur Penelitian - Suatu Pendekatan Praktik. Jakarta: PT. Rineka Cipta, Jakarta.

Dahlan, Sopiyudin. (2011). Statistik Untuk Kedokteran dan Kesehatan. Jakarta: Salemba, Edisi 5.

Ghozali, Imam. (2011). Aplikasi Analisis Multivariate Dengan Program SPSS". Semarang: BP. Undip.

Handaru, Agung W. (2012). Pengaruh Kepuasan Gaji dan Komitmen Organisasi Terhadap Intensi Turnover. Jakarta: Jurnal, Fakultas Ekonomi, Univ. Negeri Jakarta.

Handoko, T. Hani. (2008). Manajemen Personalia Dan Sumber Daya Manusia. Yogyakarta: BPFE Yogyakarta.

Harnoto. (2002). Manajemen SDM-Perilaku Organisasi. Jakarta: , PT. Prehalindo, Edisi 2.

Hasibuan, M. . (2003). Organisasi Dan Motivasi Dasar Peningkatan Produktivitas. Jakarta: T. Bumi Aksara, Jakarta. 